\title{
ANALISIS YURIDIS TERHADAP CCTV (CLOSE CIRCUIT TELEVISION) SEBAGAI BARANG BUKTI I PERSIDANGAN
}

\author{
Oleh: \\ Ismail ${ }^{1)}$, \\ dan Ahmad Nahwiy ${ }^{2)}$ \\ Universitas Asahan ${ }^{1,2)}$ \\ E-mail: \\ ismail_izu@yahoo.com ${ }^{1)}$ \\ nahwiyahmad@gmail.com $^{2)}$
}

\begin{abstract}
ABSTRAC
Legal events become a problem in daily life that is a threat to people or groups of people in living a social life. Technology exists to help regulate the law to make criminals get a deterrent effect. CCTV (Close Circuit Television) is here to help be a watchdog to assist the country in supervising daily life. What's more now CCTV has helped in criminal evidence to help find the perpetrators of crimes whose aim is to speed up the search for perpetrators and look for what evidence is carried by the perpetrators.
\end{abstract}

Keywords: CCTV (Close Circuit Television), Criminal Proof, Law on Information and Electronic Transactions, Information Technology

\begin{abstract}
ABSTRAK
Peristiwa-peristiwa hukum menjadi masalah dalam kehidupan sehari-hari yang menjadi ancaman kepada orang maupun sekelompok orang dalam menjalani kehidupan bermasyarakat. Teknologi hadir untuk membantu pengaturan hukum untuk membuat pelaku kejahatan mendapatkan efek jera. CCTV (Close Circuit Television) hadir untuk membantu menjadi pengawas untuk membantu negara dalam mengawasi kehidupan sehari-hari. Terlebih lagi sekarang CCTV telah membantu dalam pembuktian pidana untuk membantu mencari pelaku kejahatan yang tujuan nya untuk mempercepat pencarian pelaku dan mencari barang bukti apa yang dibawa oleh pelaku.
\end{abstract}

Kata Kunci: CCTV(Close Circuit Television), Pembuktian Pidana ,Undang Undang Informasi dan Transaksi Elektronik, Teknologi Informasi 


\section{PENDAHULUAN}

Dalam masa ini Teknologi menjadi hal yang sangat penting untuk membantu tatanan hukum supaya cepat dan efisien.Teknologi ini dibutuhkan untuk membantu pihak berwenang untuk menyelidik dan menyidik dalam melakukan investigasi untuk menemukan pelaku kejahatan. Dalam tindak pidana memang di butuhkan bermacam-macam bukti untuk mencari fakta-fakta yang dilakukan di tempat kejadian perkara. Dewasa ini manusia hidup dengan teknologi. Teknologi saat ini sangat membantu dalam kehidupan apapun. Khususnya norma norma yang mengatur kehidupan bermasyarakat di Indonesia supaya meningkatkan rasa aman dan tenteram dalam kehidupan sosial.ini Terjadi Karena adanya Tentu saja dikarenakan akibat tindak pidana yang terjadi karena ada sebab yang menjadi akibat dari suatu tindak pidana (causality).(Sudarsono;2007:75).

Secara Substansif, pengertian dari istilah" peristiwa pidana" lebih menunjuk kepada suatu kejadian yang dapat ditimbulkan baik oleh perbuatan manusia maupun oleh gejala alam.(Teguh Prasetyo;2011:49).

Dalam tindakan pidana seperti dalam kasus Jessica Kumala Wongso yang tertangkap CCTV yang jadi terpidana karena membunuh Wayan Mirna Solihin dengan meracuni dengan racun sianida

Terlepas dari masalah ini, pastinya sangat berhubungan dengan tindak pidana yang mana membutuhkan barang bukti yang menjadi penunjang alat bukti yang kuat dan memnuhi syarat yang bisa dipertanggung jawabkan dan bisa dibawa di persidangan.Dalam bukunya yang berjudul "Hukum Acara Pidana Indonesia “,Prof. Dr..Jur. Andi Hamzah, mengakatan bahwa Pembuktian tentang benar tidaknya terdakwa melakukan perbuatan yang didakwakan merupakan bagian yang sangat penting dalam cara pidana.(Andi Hamzah, 2008:250).

Sejarah perkembangan hukum acara pidana menunjukkan bahwa adanya beberapa sistem atau teori untuk membuktikan perbuatan Mencari kebenaran itu tidak mudah. Alat-alat bukti yang tersedia menurut Undang- Undang sangat relatif.Alat-alat bukti seperti kesaksian, menjadi kabur dan sangat relatif. Kesaksian diberikan oleh manusia yang mempunyai sifat pelupa . Bahkan menurut psikologi,penyaksian suatu peristiwa ,yang baru sajat terjadi oleh beberapa orang akan berbeda-beda. Ini berarti kesaksian yang sifat nya hanya memperkuat keyakinan hakim.

Oleh karena itu Dalam memutuskan perkara Hakim juga melihat barang bukti yang telah dihadirkan oleh pihak penyelidik untuk menjadi bahan pertimbangan Hakim dalam memutuskan perkara.Perkara yang berhubungan dengan tindak pidana dengan barang bukti ini banyak terungkap di lapangan.

Dinamika sosial pada umumnya menampilkan dirinya sebagai gerakan berpindah atau gerakan berubah, dan terdapat 3 (tiga) macam yang dapat diidentifikasikan sebagai gerakan yang menentukan dinamika sosial yakni , mobilitas horizontal, mobilitas vertikal, dan dinamika lintas budaya.(Danrivanto Budhijanto,2017:hlm28).

Perhatian yang sangat besar untuk merumuskan kepastian hukum dan keadilan terkadang menimbulkan masalah besar dalam penerapan hukum tersebut, yaitu ketertiban umum, walaupun konsiderans menimbang dalam Undang Undang Informasi dan Transaksi Elektronik memanfaatkan infrastruktur hukum dan pengaturan terjadinya penyalahgunaan, dengan memperhatikan nilai- nilai agama dan sosial budaya masyarakat indonesia.

Konsiderans menimbang UndangUndang Informasi Transaksi Elektronik secara jelas menunjukkan alasan keberlakuannya, pokok-pokok pemikiran 
dalam konsiderans pertimbangan, sebagai berikut:

a. Indonesia adalah bagian daripada bagian masyarakat informasi dunia sebagai akibat dari pada terjadinya globalisasi Informasi:

b. Perkembangan pada Teknologi Informasi berakibat terhadap perubahan kegiatan manusia dalam pelbagai bidang, dan berimbas kepada terbentuknya norma dan atau kaidah hukum baru;

Kebutuhan terhadap tersediannya infrastruktur hukum dan pengaturan dalam pemanfaatan Teknologi Informasi agar mencegah penyalahgunaan, dengan memperhatikan nilai-nilai agama dan sosial budaya masyarakat indonesia.

Berdasarkan uraian latar belakang diatas, maka skripsi ini rumusan permasalahan sebagai berikut :

1. Bagaimana pengaturan hukum tentang CCTV(Close Circuit Televisioni) sebagai barang bukti di persidangan?

2. Bagaimana kekuatan pembuktian barang bukti CCTV(Close Circuit Television) di persidangan?

\section{METODE PENELITIAN}

Penulisan jurnal ini yang mana metode yang digunakan dalam pengumpulan data untuk penyusunan skripsi ini adalah melalui studi kepustakaan (library research) yaitu berdasarkan buku-buku pustaka.

\section{HASIL dan PEMBAHASAN}

\section{A. pengaturan hukum tentang cctv sebagai barang bukti di persidangan}

Berbicara tentang pengaturan hukum, pengaturan hukum tentang bukti elektronik diatur dalam Undang-Undang No 19 Tahun 2016 tentang Informasi dan Transaksi Elektronik( juncto UndangUndang No.11 Tahun 2008 tentang
Informasi dan Transaksi Elektronik).Hukum ini pada awalnya mengatur tentang bagaimana aturan hukum secara umum.namun karena ada dinamika yang terjadi dimasyarakat, terjadi lah perubahan undang-undang ini.

Beberapa Aspek-aspek dalam Undang-Undang ITE ini sangat banyak, namun salah satu nya yang berhubungan dengan sub judul diatas adalah Aspek pembuktian elektronik.Pasal 5 ayat (2) dalam Undang-Undang No 11 Tahun 2008 tentang Informasi dan Transaksi Elektronik yang berbunyi bahwa

\section{"Informasi Elektronik dan/atau Dokumen Elektronik dan/atau hasil cetaknya sebagaimana dimaksud pada ayat (1) merupakan perluasan dari alat bukti yang sah sesuai dengan Hukum Acara yang berlaku di Indonesia".(Pasal 5 ayat (2) Undang-Undang No 8 Tahun 2008 tentang Informasi dan Transaksi Elektronik).}

Dalam pengaturan hukumnya, penyidik pejabat polisi adalah salah satu pihak berwnenang dalam menyidik suatu peristiwa hukum yang terjadi di masyarakat, tetapi sebetulnya bukan hanya penyidik, melainkan Pejabat pegawai negeri sipil tertentu di lingkungan pemerintah yang lingkup tugas dan tanggung jawabnya di bidang teknologi Informasi dan Transaksi Elektronik.

Penyidik Pegawai Negeri Sipil yang dimaksud berwenang terdapat pada penjelasan pasal 43 ayat satu adalah bahwa:

a. Menerima laporan atau pengaduan dari seseorang tentang adanya tindak pidana di bidang teknologi Informasi danTransaksi Elektronik.

b. Memanggil setiap orang atau pihak lainnya untuk didengar dan diperiksa sebagai tersangka atau saksi sehubungan dengan 
adanya dugaan tindak pidana di bidang Teknologi Informasi dan Transaksi Elektronik.

c. Melakukan pemeriksaan atas kebenaran laporan atau keterangan berkenaan dengan tindak pidana di bidang Teknologi Informasi dan Transaksi Elektronik.

d. Melakukan pemeriksaan terhadap Orang dan/atau Badan Usaha yang patut diduga melakukan tindak pidana di Bidang Teknologi Informasi dan Transaksi Elektronik.

e. Melakukan pemeriksaan terhadap alat dan/atau sarana yang berkaitan dengan kegiatan Teknologi Informasi yang diduga digunakan untuk melakukan tindak pidana di bidang Teknologi Informasi dan Transaksi Elektronik.

f. Melakukan penggeledahan terhadap tempat tertentu yang diduga digunakan sebagai tempat untuk melakukan tindak pidana di bidang Teknologi Informasi dan Transaksi Elektronik.

g. Melakukan penyegelan dan penyitaan terhadap alat dan/atau sarana kegiatan Teknologi Informasi yang diduga digunakan secara menyimpang dari ketentuan peraturan perundang-undangan.

h. Membuat suatu data dan/atau Sistem Elektronik yang terkait tindak pidana di bidang Teknologi Informasi dan Transaksi Elektronik agar tidak dapat diakses.

i. Meminta informasi yang terdapat didalam Sistem
Elektronik atau informasi yang

dihasilkan oleh Sistem

Elektronik Kepada

Penyelenggara Sistem

Elektronik yang terkait dengan tindak pidana dibidang Teknologi Informasi dan Transaksi Elektronik.

j. Meminta bantuan ahli yang diperlukan dalam penyidikan terhadap tindak pidana dibidang Teknologi Informasi dan Transaksi Elektronik

k. Mengadakan penghentian penyidikan tindak pidana di bidang Teknologi Informasi dan Transaksi elektronik sesuai dengan ketentuan Hukum Acara Pidana

Rekaman Video sangat membantu dalam melihat kapan peristiwa hukum itu terjadi karena pastinya rekam digital memiliki waktu yang tersimpan. Dalam hal ini sangat penting untuk mengetahui Bagaimana para tersangka melakukan nya dan benda apa yang digunakan untuk melakukan tindak kejahatan.Tentu saja sangat membantu pihak penyidik untuk memutuskan waktu peristiwa itu dilakukan oleh tersangka tersebut. Pembuktian merupakan masalah yang dalam faktanya mempunyai peranan sangat penting dalam persidangan.

Hal itu terdapat dalam pasal 184 Kitab Undang-Undang Hukum Acara Pidana berisi bahwa alat bukti yang sah ialah: (Pasal 184 Kitab Undang-Undang Hukum Acara Pidana)
a. keterangan saksi
b. keterangan ahli
c. surat
d. petunjuk
e. keterangan terdakwa 
Pengaturan Hukum dalam Pasal 3 Undang-Undang Informasi dan Transaksi Elektronik ini juga harus mempunyai kemanfaatan hukum ,sifat kehati-hatian, iktikad baik, kebebasan memilih teknologi, atau netral teknologi.Dalam Buku Danrivanto Budhijanto(2017;136-137), Ada asas-asas yang sangat diperhatikan untuk memanfaatkan Teknologi Informasi dan Transaksi Elektronik antara lain.

a. Asas Kepastian Hukum berarti landasan hukum bagi pemanfaatan Teknologi Informasi dan Transaksi Elektronik serta segala sesuatu yang mendukung penyelenggaraan yang mendapatkan pengakuan hukum didalam dan diluar pengadilan.

b. Asas Manfaat berarti asas bagi pemanfaatan Teknologi Informasi dan Transaksi Elektronik di upayakan untuk mendukung proses berinformasi sehingga dapat mengoptimalkan kesejahteraan masyarakat

c. Asas Kehati-hatian berarti landasan bagi pihak yang bersangkutan harus memperhatikan segenap aspek yang berpotensi menimbulkan kerugian, baik bagi diri sendiri maupun orang lain untuk memanfaatkan Teknologi Informasi dan Transaksi Elektronik ini

d. Asas Itikad Baik berarti Asas ini tidak bertujuan untuk secara sengata dan tanpa hak atau melawan hukum mengakibatkan kerugian bagi pihak lain tanpa sepengetahuan pihak lain.

e. Asas Kebebasan Memilih Teknologi atau Neutral Teknologi yang berarti Pemanfaatan Teknologi Informasi dan Transaksi
Elektronik tidak hanya fokus pada pemanfaatan teknologi tertentu

Dengan ini diharapkan masyarakat juga harus lah belajar bagaimana memanfaat teknologi dengan baik. Karena sekarang di era digital ini semua serba cepat dan sederhana. Bayangkan kalo mungkin tidak ada kamera pengawas atau pun CCTV(Close Circuit Television) ini mungkin kita tidak akan tau apa yang terjadi sebenarnya dan juga bagaimana peristiwa itu terjadi dengan sendirinya mungkin tidak ada yang tau.

Dalam pengaturan hukumnya ini perlu mempelajari kejahatan" tingkah laku manusia", maka pendekatan Deskriptif itu adalah salah satu dasar penting untuk mempelajari bagaimana manusia dalam mempelajari Teknik Kejahatan yang terjadi di masyarakat terutama apa yang di lakukan pelaku pada saat terekam kamera CCTV(CloseCircuitTelevision).pendekata $\mathrm{n}$ ini dikenal dengan cara "observasi" dan pengumpulan data seperti;usia, jenis kelamin, warna rambut. dan perkembangan karir pelaku kejahatan.(Yesmil Anwar ,2010:37-38)

Pentingnya juga hal ini agar menjadi pertimbangan hakim tentang bagaimana perilaku pelaku pada saat peradilan untuk mengetahui tujuan mereka.bukti-bukti persidangan ini menjadi kunci bagaimana kejahatan itu terjadi.

Terkadang pada saat terekam kamera CCTV, terjadi hal yang tak terduga seperti orang melakukan tanda-tanda seperti gerakan- gerakan rahasia ataupun kode morse, atau pun tanda tanda yang bisa menjadi petunjuk.

Hal ini terdapat dalam pasal 1 ayat (6) Peraturan pemerintah no 82 tahun 2012 bahwa "Informasi Elektronik adalah satu atau sekumpulan data elektronik, termasuk tetapi tidak terbatas pada tulisan, suara, 
gambar, peta, rancangan, foto, electronic data interchange (EDI), surat elektronik (electronic mail), telegram, teleks, telecopy atau sejenisnya, huruf, tanda, angka, kode akses, simbol, atau perforasi yang telah diolah yang memiliki arti atau dapat dipahami oleh orang yang mampu memahaminya.".artinya pada saat seseorang mengirimkan suatu bukti elektronik tetapi maksud dari bukti itu, maka diperlukan lah orang yang cukup paham dalam memahami maksud dari kode atau pun gerakan rahasia. Biasanya ini dilakukan oleh para Tentara Nasional Indonesia (TNI) yang terkadang membuat gerakan-gerakan yang memiliki maksud yang hanya dipahami oleh yang mengetahui gerakan itu.

Mengingat memang Alat bukti elektronik ini belum tentu semua orang memahami pentingnya sebuah bukti bahkan hal sekecil apapun bisa dikatakan pun dianggap sepele. Padahal hal itu bisa menjadi sebuah keuntungan bila digunakan dengan sangat baik. Tetapi banyak juga yang memanfaatkan hal ini menjadi lumbung kejahatan untuk mencari keuntungan demi kekayaan dan materi. Hal ini juga diharapkan bisa menjadi Pekerjaan Rumah bagi para penegak Hukum dan seluruh warga negara Indonesia.Soerjono Soekanto (Danrivanto Budhijanto,2017:127) dalam Buku Sosiologi Hukum Dalam Masyarakat menyatakan bahwa faktor-faktor yang mempengaruhi efektivitas hukum, sebagai berikut:

a. Kaidah Hukum/peraturan hukum itu sendiri

b. Petugas/Penegak Hukum

c. Fasilitas

d. Masyarakat

Kontrol sosial ternyata juga menjadi dasar pembentukan UndangUndang Informasi dan Transaksi Elektronik karena kemajuan yang pesat di bidang Teknologi Informasi pada saat ini. Tegaknya hukum tidak dapat dilepaskan dengan kenyataan berjalannya undangundang itu di masyarakat.Masih terdapat tujuan hukum lain, yaitu keadilan yang tercipta dapat menjadi kondisi damai di masyarakat dan apabila kedamaian dapat tercapai kedamaian akan melahirkan ketertiban hukum.

\section{B. kekuatan pembuktian barang bukti cctv (close circuit television) di persidangan}

Dalam pembuktian suatu perkara mungkin orang awam juga bertanya apakah Informasi Elektronik bisa dijadikan sebagai alat bukti.Dalam pasal 5 ayat (1) Undang Undang No. 11 Tahun 2008 Informasi dan Transaksi Elektronik berbunyi bahwa" Informasi Elektronik dan/atau Dokumen Elektronik dan/atau hasil cetakannya merupakan alat bukti hukum yang sah". Tentu saja hal ini menjadi acuan bahwa CCTV(CLOSE CIRCUIT TELEVISION) ini di perbolehkan untuk menjadi alat bukti karena termasuk informasi Elektronik yang menampilkan situasi untuk memberikan informasi sebagai sistem keamanan tambahan karena di era ini banyak cara dilakukan oleh para pelaku kejahatan untuk mempermudah kinerja mereka untuk melakukannya dengan aman.

Berbicara tentang kekuatan pembuktian, memang inilah hal terpenting disaat persidangan berlangsung. Melihat hal ini terkadang banyak hal-hal yang tak terduga. Hal ini terjadi karena para-para terdakwa,tergugat,dan terlapor ingin menunjukkan bahwa mereka juga punya kekuatan bukti yang kuat untuk meyakinkan para Majelis Hakim untuk memberikan pertimbangan yang seadiladilnya dalam memberikan putusan pengadilan.

Alat bukti Elektronik perlu di kaji secara teliti agar tidak terjadi kesalahpahaman yang mengakibatkan hal 
yang fatal yang membuat putusan itu menjadi kacau. Jika dilihat hal ini sangat penting jika ditinjau dari saksi ahli elektronik pada saat meneliti kasus Jessica Kumala Wongso yang terekam kamera CCTV(Close Circuit Television) itu sangat lah detil mulai dari hal-hal yang kecil sampai ke hal-hal yang tidak terpikirkan akal manusia. dengan detail para saksi ahli menjelaskan pada hakim itu dengan ilmu yang mereka punya. Maka dari itu peran saksi ahli adalah hal yang vital atau penting dalam menganalisis kejadian para pelaku kejahatan.

Keterangan ahli khususnya dalam perkara pidana sangat penting.Hal ini terdapat dalam pasal 1 angka 28 yang berbunyi bahwa "Keterangan ahli adalah keterangan yang diberikan oleh seorang yang memiliki keahlian khusus tentang hal yang diperlukan untuk membuat terang suatu perkara pidana guna kepentingan pemeriksaan.Dalam hal ini keterangan ahli itu bukan hanya dalam aspek-aspek ilmu hukum, namun berbagai macam aspek keilmuan pun juga di butuhkan dalam hal ini. Misalnya dalam menganalisis video rekaman CCTV(Close Circuit Television) dalam Kasus Jessica Kumala Wongso yang terbukti membunuh Wayan Mirna Salihin dengan racun sianida dengan berbagai cara. Dalam hal ini juga dipanggil saksi ahli dalam bidang kesehatan ataupun bidang farmasi untuk meneliti kenapa dan racun seperti apa yang digunakan terpidana dalam membunuh si korban itu.Yang kita tau hakim juga tak bisa memutuskan secara sederhana dalam memutuskan perkara. Peran penting ini tidak lepas karena tidak semua orang dapat menguasai semua ilmu pengetahuan.

Biasa nya dalam hukum juga di panggil team dokter forensik .biasanya mereka meneliti bagaiamana ketika seseorang telah meninggal. Biasanya nya mereka mencari data data rekam medic (medical record) untuk diteliti apakah memang penyebab meninggal nya orang tersebut karena penyakit tersebut atau ada sebab-sebab lain yang harus di teliti lebih lanjut.Hal-hal ini terjadi karena kekurangan petunjuk yang sebetulnya bukti itu sudah ada Tetapi dikarenakan hal ini menjadi pertimbangan karena membutuhkan keahlian khusus dalam suatu perkara yang membutuhkan analisis bukti yang kurang dipahami oleh orang biasa.

Sayangnya dalam hal ini, saksi ahli ini jumlah nya cukup terbatas dan biasanya kebanyakan hanya berada di daerah Ibu Kota Provinsi.mungkin dikarenakan proses seleksi yang sebetulnya cukup banyak namun memang tidak sembarang orang bisa menjadi saksi ahli.

Dalam Pasal 7 dalam UndangUndang No 11 Tahun 2008 berbunyi bahwa"Setiap orang menyatakan hak, memperkuat hak yang telah ada, atau menolak hak Orang lain berdasarkan adanya Informasi Elektronik dan/atau Dokumen Elektronik harus memastikan bahwa Informasi Elektronik dan/atau Dokumen Elektronik yang ada padanya berasal dari Sistem Elektronik yang memenuhi syarat berdasarkan Peraturan Perundang-undangan. Dalam hal ini jelas bahwa semua orang yang cakap dalam hukum berhak untuk membela,membantu pembelaan, ataupun memperberat suatu orang yang sedang didakwa dengan membuktikan bukti bukti elektronik yang dapat diakses, dijamin keutuhannya dan dapat dipertanggung jawabkan.Hal ini juga diatur dalam pasal 6 Undang-Undang no 11 tahun 2008 berbunyi bahwa"Dalam hal terdapat ketentuan lain selain yang diatur dalam pasal 5 ayat (4) yang mensyarakat bahwa suatu Informasi harus berbentuk tertulis atau asli, Informasi Elektronik dan/atau Dokumen Elektronik dianggap sah sepanjang informasi yang tercantum di dalamnya dapat diakses, ditampilkan, dijamin keutuhannya, dan dapat di pertanggungjawabkan sehingga dapat 
memperjelas dan menerangkan suatu keadaan.

\section{Berbicara dengan kekuatan} pembuktian Elektronik. Di negara seperti Amerika Serikat ini sudah seperti hal yang wajib apabila dirumah mereka di pasang CCTV karena mengingat negara maju juga yang pasti berbagai kejahatan pun juga mempunyai pemikiran kejahatan yang sangat tinggi. Sebetulnya hal ini memang menurut penulis berasumsi bahwa di Negara Amerika Serikat ini juga karena juga sudah tinggi angka kejahatan,maka kemungkinan pada masa itu.

Namun kekurangannya ini bisa dimanfaat oleh orang-orang yang sengaja memanipulasi untuk membuat orang yang tidak ada apa-apa hubungannya menajdi orang yang menjadi diduga bersalah. Ini bisa menimbulkan eror in persona dimana seseorang yang bukan pelaku sebenarnya tetapi harus menanggung akibat dari orang yang seharusnya bersalah namun melakukan manipulasi untuk bebas dari hukuman pidana.

Persoalan ini sebetulnya mungkin saja banyak terjadi. Namun sebetulnya banyak yang lolos dari jeratan pidana yang terkadang juga banyak menghadirkan banyak saksi-saksi palsu untuk memberikan kesaksian palsu yang sebetulnya dibuat hal yang tidak sesuai dengan fakta.

Hal-hal mengenai kekuatan pembuktian harus lah di pertanggung jawabkan karena menilai masalah keabsahan bukti yang diberikan di persidangan.Didalam pembuktian ini memang harus benar-benar harus mempertanggung jawabkan bukti itu. Beberapa orang berpikir dalam dirinya bahwa kalau pun perkembangan kriminologi sudah sempurna. Maka tidak boleh lagi adanya pidana. Namun fakta nya masih banyak dilakukan.Kalau penjahat diibaratkan orang sakit,dan pidana yang bersifat memberi nestapa sebagai pembalasan atas kejahatan yang dilakukan.Adapun cara untuk mencapai usaha pemasyarakatan ini adalah bermacam macam, yang boleh berganti dan berubah berdasarkan ilmu pendidikan dalam bidang tersebut. (Moeljatno,2015:15-16).

Hukum pidana yang berlaku di Indonesia ini adalah hukum yang telah di kodifikasi.Selain itu juga hukum pidana Indonesia ini juga sudah di unifikasi, artinya berlaku untuk seluruh golongan rakyat.Unifikasi udah lama sejak tahun 1918, yaitu pada saat berlaku nya undang undang dari belanda.hukum pidana ini bersifat umum karena masuk dalam hukum publik yang artinya masalah yang terjadi itu pemerintah harus turun tangan menangani masalah hukum di masyarakat. Inilah yang terjadi bila pada saat pembuktian di persidangan sangat susah untuk menentukan pilihan untuk menetapkan pihak terdakwa.Bisa saja dia dijebak dan memang direncanakan seolah olah memang seseorang yang dijebak itu lah pencuri nya.

Jika melihat rekaman $\mathrm{CCTV}($ Close Circuit Television) juga kita melihat mungkin saja seorang yang pada saat itu belum dewasa melakukan tindak pidana.Dalam pasal 45 Kitab UndangUndang Hukum Pidana berbunyi bahwa "Dalam hal penuntutan pidana terhadap orang yang belum dewasa karena melakukan suatu perbuatan sebelum umur enam belas tahun, hakim dapat menentukan".Dalam hal ini dapat memilih antara ketiga kemungkinan, antara lain

a. Mengembalikan anak tersebut kepada orang tuanya tanpa diberi pidana apa pun .

b. Menyerahkan anak tersebut kepada pemerintah untuk dimasukkan rumah pendidikan.

c. Menjatuhi pidana seperti orang dewasa. Hukuman maksimal 
pidana nya adalah $1 / 3$ dari hukuman pokok.

Mengingat ini adalah hal yang sangat penting pada saat pembuktian yang terlihat tanggal kejadiannya apakah dia belum cukup berusia diatas 17 tahun atau tidak. Maka pada saat itu hukumannya masih dianggap berusia 16 tahun.

Penting untuk diingat, prerogatif hakim itu sangat penting dalam menindak terdakwa apakah memang layak atau tidak dijatuhi pidana.Hati nurani Hakim sangat penting untuk mengingat hal ini juga menjadi masalah serius dalam memutuskan perkara.

Terkait dengan hal ini juga berbicara tentang Independensi Hakim yang mana baiknya peradilan itu harus lah bersifat Independen, tidak berada di pihak manapun.

Hakim pada saat mengadili perkara tidak boleh memberikan kesan bahwa salah satu pihak berperkara mempunyai kedudukan istimewa,dan hal ini dapat mempengaruhi hakim.Hakim dilarang bersikap mengeluarkan perkataan atau melakukan tindakan yang menimbulkan kesan memihak, berprasangka, mengancam, menyudutkan dalam suatu perkara.Hakim juga harus menjalankan sesuai dengan kode etik, ketentuan hukum, dan perilaku, dan lain-lainnya.Terkadang terjadi ketidakpuasan pada majelis hakim karena hal hal yang terjadi di persidangan.Unjuk rasa terhadap ketidakpuasan tersebut tidak sedikti berakhir anarkis dan sampai menimbulkan korban jiwa. Ketidakpuasan ini sudah hal yang biasa terjadi di masyarakat bahkan di masyarakat adat juga mengalami hal seperti ini yang mana hal hal yang berdasaran SUKU, ADAT,dan RAS.

Seorang Hakim harus menjalankan tugas dengan baik memang terkadang belum tentu akuntabilitasnya dinilai dengan baik bahkan malah kebalikannya dinilai buruk.Hal-Hal ini bisa diasumsi bahwa terkadang suatu hal yang menjadi pertimbangan hakim. Dalam rangka mencari hakim yang baik, perlu dilakukan kerjasama antara lembaga/badan yang tugasnya dalam permasalahan pengangkatan, pemberhentian, mutasi, kenaikan pangkat, penggajian maupun yang berkaitan dengan masalah penindakan di bidang hukum administratif sebelum diadakan rekrutmen pengangkatan maupun pemberhentian dan lain-lain.

Dinilai dari kekuatan CCTV, ada juga kelemahan-kelemahan yang bisa dimanfaatkan oleh para pelaku kejahatan yang terkadang CCTV itu juga rentan terhadap sabotase-sabotase yang terjadi di lapangan. Dikarenakan ada beberapa hal yang dilakukan untuk melakukan sabotase itu mulai dari pencurian data video,data perangkat lunak, dan sistem elektroniknya.

Hal ini memang dilakukan untuk menyulitkan penyelidik dan penyidik untuk mencari petunjuk-petunjuk untuk mencari pelaku sebenarnya karena hal itulah yang diingikan bagi pelaku agar bisa lepas dari rantai-rantai hukum.Ketika suatu bukti hilang, maka kemungkinan pasti sulit mencari karena bukti-bukti penting yang dirusak untuk menghilangkan kejadiankejadian hukum yang sebenarnya yang menjadi bukti kunci dalam pembuktian pidana pada saat penyelidikan dan penyidikan. Para para penyelidik ini mencari keseluruhan untuk menyesuaikan fakta-fakta investigasi Tempat Kejadian Perkara (TKP).

Menurut Penjelasan Danrivanto (2017:52) ,Penyelidikan dan penyidikan ini harus melakukan penggeledahan dan/atau penyitaan serta penangkapan dan penahanan yang dirumuskan dalam Undang Undang Informasi dan Transaksi Elektronik dengan rumusan peraturan KUHAP ini menjadi kesimpulan, sebagai berikut. 
a. Pengaturan penggeledahan dan/atau penyitaan dalam Undang Undang Informasi dan Transaksi Elektronik secara absolut memberikan pengawasan langsung kepada Ketua Pengadilan Negeri.

b. Pengaturan tentang penangkapan penahanan oleh penyidik wajib meminta izin ketua pengadilan melalui penuntut umu dalam waktu $1 \times 24$ jam.

Mengingat hal ini ada beberapa yurisprudensi di luar negeri tentang alat bukti elektronik yang menjadi bahan pertimbangan hakim antara lain

1. "Putusan hakim (perdata) Pengadilan Uni Eropa No $1206 / 2001$, yang dijatuhkan pada tanggal 24 Mei 2001 dan berkekuatan hukum tetap pada Tanggal 1 Januari 2004. Dalam pembuktiannya membuktikan telekonference dan video conference untuk mendengarkan pemeriksaan saksi dan juga memperkenankan penyampaian permohonan/gugatan melalui media elektronik (E-mail)".

2. "Putusan Pengadilan Tinggi Den Boch No.290/HJF/2005, tanggal 3 Mei 2005, dengan melakukan pemeriksaan saksi yang berada di Berlin didengar kesaksiannya melalui teleconference di pengadilan Den Boch Belanda".

Dalam teori Hukum pembuktian disebutkan bahwa agar suatu alat bukti yang diajukan di persidangan sah sebagai alat bukti, harus dipenuhi secara formil dan materil yang sesuai didalam undangundang.
Hukum formil pidana memang menyangkut bagaimana masalah pengaturan hukum dan kekuatan hukum pembuktian ini diatur dari tahap penyelidik, penyidik, penahanan, pra-peradilan, peradilan hingga putusan.

Pembuktian mempunyai peran penting di persidangan. Kriminalitas yang menimbulkan banyak kerugian mempunyai barang barang bukti kejahatan yang tidak terduga. Apalagi kalo menyangkut tindak pidana Terorisme yang sangat ditakuti masyarakat. Terutama pada saat Ledakan di JW Marriot dan Riltz Carlton pada tahun 2009 yang terekam kamera CCTV (Close Circuit Television).

Peristiwa peristiwa terorisme yang terekam video ini mejadi bukti kejamnya terorisme yang meledak dengan cara bom bunuh diri. Memang masalah teroris ini sangat sensitif karena banyak oknum mengkaitkannya dengan agama. sangat disayangkan memang para para pelaku ini mengatas namakan agama dalam perbuatan yang tujuannya salah.Mungkin saja kalo tidak ada rekaman CCTV(Close Circuit Television) ini kita tidak tau apa yang terjadi pada saat itu dan mungkin dengan hal ini menjadikan kita semua terbuka pikiran kita untuk tetap berhatihati disaat apapun.

Penyelidikan pada saat itu menemukan orang bunuh diri dengan bom yang di pasangkan di tubuhnya. Kebetulan pada saat itu tim sepak Bola Terkenal dari Inggris yang bernama Manchester United harus membatalkan kunjungan nya untuk melakukan tindak preventif (pencegahan). Pada saat itu sangat disayangkan sekali tim sepak bola terkenal itu tidak bisa datang dikarenakan hal ini. Banyak penggemar sepakbola tidak bisa menahan kekecewaan nya pada saat mendengar berita itu.

Dalam Buku Margono (2019:128), Soerjono Soekanto mengatakan Soal faktor faktor hakim dalam mempengaruhi 
penegakan hukum ada beberapa hal yaitu bahwa:

a. Faktor hukumnya sendiri, yang dalam hal ini terbatas pada undang-undang saja

b. Faktor penegak hukumnya, yakni pihak-pihak yang membentuk maupun yang menerapkan hukum.

c. Faktor sarana atau fasilitas yang mendukung penegakan hukum.

d. Faktor masyarakat, yaitu lingkungan dimana hukum ditegakkan.

e. Faktor kebudayaan.

\section{KESIMPULAN}

CCTV (Close Circuit Television) menjadi bukti elektronik yang sah dan di akui di pengadilan dengan syarat formil dan syarat materiil. Pembuktianpembuktian ini dikarenakan memang karena adanya perkembangan teknologi dan Tingkat Kejahatan yang bisa dibilang tingkatannya bukan hanya tinggi namun juga terstruktur dan masif.

Kekuatan-Kekutatan CCTV ini sangatlah berperan penting dalam melihat kejadian apa yang sebenarnya terjadi pada saat terjadinya peristiwa-peristiwa Hukum yang mengakibatkan terjadinya akibat Hukum yang mengakibatkan ruginya seseorang, kelompok ataupun Badan Hukum yang mengalami kejadian itu. Disamping itu juga pembuktian pembuktian Elektronik ini gunanya sangat membantu para aparat penyelidik dan penyidik dalam menjalankan tugastugasnya untuk menyikap tabir-tabir hukum yang terjadi di masyarakat.Dan hal lain juga sangat membantu Para Majelis Hakim Untuk menganalisis Logika-Logika Hukumnya dalam menyaksikan peristiwa- peristiwa yang terekam pada saat terjadi nya hal tersebut. Dan juga hal ini menjadi pertimbangan hakim untuk memutuskan perkara dan menjadi yurisprudensi untuk bisa dijadikan bahan bahan kajian untuk para hakim yang akan datang.

\section{DAFTAR PUSTAKA}

Anwar, Yesmil dkk. 2010, Kriminologi. Bandung. Refika Aditama

Budhijanto,Danrivanto .2017. Revolusi Cyber Law Indonesia. Bandung : Refika Aditama

Hamzah,Andi. 2008 .Hukum Acara Pidana Indonesia .Jakarta: Sinar Grafika

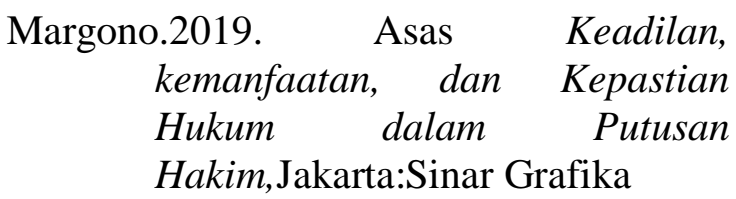

Moeljatno. 2015. Asas-Asas Hukum Pidana.Jakarta:Rhineka Cipta

Prasetyo, Teguh. 2015. Hukum Pidana Edisi Revisi. Jakarta :Rajawali Pers

Sudarsono.2007.Kamus Hukum .Jakarta : Rineka Cipta 